\title{
New permafrost is forming around shrinking Arctic lakes, but will it last?
}

Martin A. Briggs ${ }^{1}$, Michelle A. Walvoord², Jeffrey M. McKenzie ${ }^{3}$, Clifford I. Voss ${ }^{4}$, Frederick D. Day-Lewis ${ }^{1}$, and John W. Lane ${ }^{1}$

${ }^{1}$ Office of Groundwater, Branch of Geophysics, U.S. Geological Survey, Storrs, Connecticut, USA

${ }^{2}$ National Research Program, Central Branch, U.S. Geological Survey, Lakewood, Colorado, USA

${ }^{3}$ Department of Earth and Planetary Sciences, McGill University, Montreal, Quebec, Canada

${ }^{4}$ National Research Program, U.S. Geological Survey, Menlo Park, California, USA

\section{Abstract}

Widespread lake shrinkage in cold regions has been linked to climate warming and permafrost thaw. Permafrost aggradation, however, has been observed within the margins of recently receded lakes, in seeming contradiction of climate warming. Here permafrost aggradation dynamics are examined at Twelvemile Lake, a retreating lake in interior Alaska. Observations reveal patches of recently formed permafrost within the dried lake margin, colocated with discrete bands of willow shrub. We test ecological succession, which alters shading, infiltration, and heat transport, as the driver of aggradation using numerical simulation of variably saturated groundwater flow and heat transport with phase change (i.e., freeze-thaw). Simulations support permafrost development under current climatic conditions, but only when net effects of vegetation on soil conditions are incorporated, thus pointing to the role of ecological succession. Furthermore, model results indicate that permafrost aggradation is transitory with further climate warming, as new permafrost thaws within seven decades.

\section{Introduction}

Major drops in lake level over the past 30 years in Arctic and subarctic regions have been tied to climate warming [Smith et al., 2005; Labrecque et al., 2009; Anderson et al., 2013]. Previous studies have focused on permafrost thaw mechanisms contributing to declines in lake [Yoshikawa and Hinzman, 2003; Jepsen et al., 2012a, 2013] and wetland [Avis et al., 2011] areas, with little attention to permafrost aggradation as a potential factor in the cycle of surface water redistribution. Here we seek to understand permafrost aggradation around shrinking Arctic lakes in terms of ecological feedback. Permafrost aggradation around Arctic lakes has important implications for (1) predicting carbon release around lakes in cold regions, (2) predicting the evolution of wetlands around shrinking lakes, and (3) modeling of groundwater/surface water interaction in regions of discontinuous permafrost.

Permafrost, defined as ground frozen for two or more consecutive years, acts as an impediment to water flow [Woo and Winter, 1993; Wellman et al., 2013]; thus, its distribution 
near the margins of lakes controls lake-groundwater interactions, moisture conditions, soil temperature, ground stability, and vegetation [Jorgenson et al., 2001; Christensen, 2004]. When Arctic lakes within the cold, continuous ( $>90 \%$ of area frozen) permafrost zone drain, new permafrost has been observed to form and thicken almost immediately following lakebed exposure [Mackay, 1997]. Response to lake recession is less understood in the warmer, discontinuous (50-90\% of area frozen) permafrost zone, where multiple interactions among water, soil, vegetation, and snow are important determinants of permafrost distribution [Jorgenson et al., 2010]. New permafrost development in the discontinuous zone has been correlated to Sphagnum and shrub growth in previously open meadow suggesting an important ecosystem driver of aggradation [Shur and Jorgenson, 2007].

Research at Twelvemile Lake in the Yukon Flats of Alaska has revealed previously unknown details about permafrost distribution and dynamics associated with lake recession in discontinuous permafrost (Figure 1). Airborne electromagnetic surveys suggest that unfrozen conditions exist below Twelvemile Lake (i.e., an open talik) and relatively thick $(\sim 90 \mathrm{~m})$ permafrost exists outside the perimeter of the recent highstand of the lake in the mid-1980s [Jepsen et al., 2012a; Minsley et al., 2012]. Therefore, as the lake recedes, exposed open meadow is, at least initially, free of permafrost. Over the past two decades willow shrubs have grown in discrete clumps/bands throughout the previously open meadow area through the process of ecological succession.

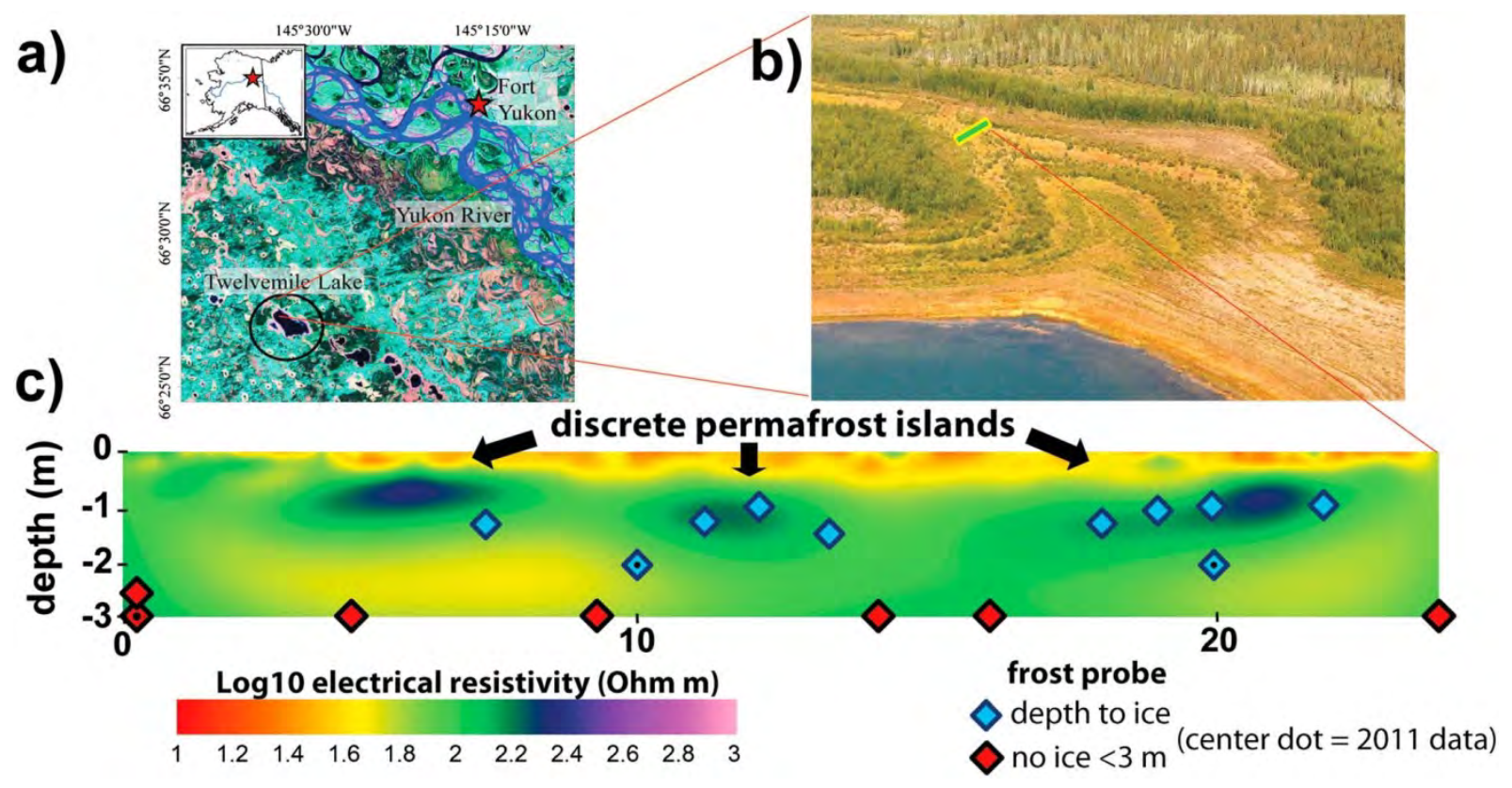

Figure 1. (a) The Twelvemile Lake site, south of the Yukon River in central Alaska. (b) Discrete bands and clumps of predominantly willow shrub vegetation are evident within the dried margin of Twelvemile Lake, bounded by contiguous spruce and deciduous forest that is generally underlain by thick (>100 m) permafrost. (c) Cross section of electrical resistivity along the profile collected in late summer 2012 shown in Figure $1 \mathrm{~b}$. Discrete resistive zones in the subsurface indicate permafrost aggregation that was confirmed with physical frost probing and other methods. 
Deciduous shrub growth reduces annual direct short-wave radiation to soil due to summer canopy shading [Shur and Jorgenson, 2007]; soil beneath shrub locations within the dried lake margin at the field site has been found to be cooler in the summer than open meadow locations. Additionally, recharge infiltration is reduced during the growing season as shrubs intercept and take up water, impeding the downward advection of summer heat. In contrast, increasing shrub abundance on Arctic tundra may trap winter snow, elevating soil temperatures [Sturm et al., 2005]; however, this process has not been observed during winter field campaigns to Twelvemile Lake, perhaps due to nearby spruce forests decreasing wind fetch compared to open tundra.

Here we assume that newly forming shrubs have a net cooling effect on the soil and test various combinations of summer shading boundary conditions and recharge reduction to determine the sensitivity of permafrost aggradation to these potential ecosystem drivers. A predicted climate warming trend is also simulated to investigate the permanence of this new frost in a changing climate.

\section{Methods}

Based on observations of permafrost aggradation at Twelvemile Lake, a suite of 100 year vertical one-dimensional (1-D) computer simulations was used to represent various ecosystem effects (reduced recharge and summer cooling from shading) and climate change using a coupled variably saturated flow and heat transport code, SUTRA [Voss and Provost, 2002], enhanced to simulate freeze-thaw [McKenzie et al., 2007; Wellman et al., 2013]. Unsaturated zone dynamics have not been considered in previous numerical modeling of permafrost aggradation. The simulations were designed to (1) test the hypothesis that permafrost can form under current conditions in response to lake recession, (2) gain insight into factors controlling permafrost formation, and (3) evaluate the response to climate warming. The open meadow with summer recharge (OM-R) scenario serves as a base case representing receded lake conditions prior to shrub succession. Prescribed model ground surface temperature and recharge boundary conditions for OM-R reflect local observations and history (Natural Resources Conservation Service Snow Telemetry Station \#961) (see Figure S2 in the supporting information). For comparison, we considered various combinations of shading at two levels (Sh1 and Sh2), summer recharge at the current level and zero level ( $\mathrm{R}$ and $0 \mathrm{R}$, respectively), and climate warming (CW), for a total of seven models: OM-R, Sh1-R, Sh2-R, OM-0R, Sh1-0R, Sh2-0R, and Sh2-0R-CW. For the shading scenarios, moderate reductions of $1{ }^{\circ} \mathrm{C}(\mathrm{Sh} 1)$ and $2{ }^{\circ} \mathrm{C}(\mathrm{Sh} 2)$ in peak summer shallow soil temperatures (defined at $0.06 \mathrm{~m}$ model depth) were based on observed willow shrub shading effects in a similar setting [Smith, 1975]; these values approximate the average apparent cooling effect of $0.6^{\circ} \mathrm{C}$ at $0.5 \mathrm{~m}$ depth under discrete willow clumps $(\mathrm{n}=5)$ compared to adjacent open meadow areas $(n=5)$ measured at the field site in late summer 2013. A conceptual schematic of the study site defined by the 1-D models is shown in Figure S1.

Summer recharge averages $0.1 \mathrm{~m}$ in the Twelvemile Lake area (SNOTEL \#961), well below the maximum potential for willow evapotranspiration; therefore, effective zero recharge $(0 \mathrm{R})$ is a plausible condition. The strongest ecosystem effect considered was a $2{ }^{\circ} \mathrm{C}$ reduction in maximum shallow soil temperatures and no summer recharge (Sh2-0R). The silt-loam soils at Twelvemile Lake were simulated using the recently measured unsaturated soil water freezing and soil water retention characteristics of similar materials [Watanabe et al., 2011; Kurylyk and Watanabe, 2013]. 


\subsection{Observations}

Multiple methods were used to determine the distribution of permafrost aggradation within the dried margin of Twelvemile Lake $\left(66^{\circ} 27^{\prime} \mathrm{N}, 145^{\circ} 34^{\prime} \mathrm{W}\right)$ in late summer 2011 and 2012. Physical methods included frost probing, for which a $3.7 \mathrm{~m}$ metal rod was manually inserted vertically into the soil to test for refusal, generally indicating frost or gravel. The probe tip was equipped with a thermistor to help discriminate refusal due to frost from refusal due to other hard surfaces. Soil pits were dug by hand in both willow and open meadow areas to 1.2 and $2.2 \mathrm{~m}$ depths, respectively, and pit walls were sampled at $0.2 \mathrm{~m}$ vertical resolution for soil type, temperature, and moisture. Exposed soil was classified as "silt loam" for both meadow and willow areas, and vertical thermal profiles were compared to model results. Electrical resistivity tomography was performed using a SuperSting R8 IP (Advances Geosciences, Inc.) eightchannel resistivity meter with $2.0 \mathrm{~m}$ and $0.5 \mathrm{~m}$ linear electrode spacing along the same transects surveyed with the physical methods.

\subsection{Numerical Simulations}

The 1-D models were constructed with a modified version of the SUTRA model that allows for variable thermal and hydraulic properties as a function of ice content [McKenzie et al., 2007]. Specified model parameter values describing the general thermophysical characteristics of liquid, ice, and solid matrix (Table S1) followed those used in recent modeling studies [McKenzie and Voss, 2013; Wellman et al., 2013] except for solid grain thermal conductivity which was chosen to represent the field site's silt/loam soil at $1.0 \mathrm{Js}-1 \mathrm{~m}-1 \mathrm{C}-1$ [Al Nakshabandi and Kohnke, 1965]. The domain spanned an elevation of $+1 \mathrm{~m}$ to a depth of $-20 \mathrm{~m}$, with the datum being the ground surface. The upper $1 \mathrm{~m}$ represented a thermal boundary layer [McKenzie et al., 2007; McKenzie and Voss, 2013] for a sinusoidal annual thermal input. The upper model domain spanned $0-5 \mathrm{~m}$ in depth and consisted of $0.01 \mathrm{~m}$ vertical elements. The water table at $-3.0 \mathrm{~m}$ was represented as a zero-pressure boundary, simulating the control of a constant lake level on water table, based on observations over the 2011-2012 field seasons and lidar elevation data collected in 2009. Therefore, the model domain from 0 to $3 \mathrm{~m}$ depth was variably saturated through time (discussed below). The static water table assumption inherently simplifies true field behavior, where the depth to saturation may be influenced by seasonal lake levels and major infiltration events including snowmelt; the effects of water table fluctuation on shallow freeze/thaw dynamics are not explored here. The lower model domain, from 5 to $20 \mathrm{~m}$ depth, comprised a vertical column of elements $0.1 \mathrm{~m}$ thick to simulate the deeper saturated zone and the geothermal gradient from below the penetration depth of the annual temperature envelope.

The initial condition for each model was the result of an 80 year equilibration run of the OM-R model using a sinusoidal annual thermal input with an amplitude of $16^{\circ} \mathrm{C}$ and a mean of $0.5^{\circ} \mathrm{C}$, similar to observed ground temperatures within the dried lake boundary near the study site [Jepsen et al., 2012b] (Figure S2). The phase of the annual temperature sinusoid was shifted forward in time by 3 months (pi/2) to best coincide the onset of snowmelt with a few-day lag of boundary temperature rising above $0^{\circ} \mathrm{C}$ in April. Once initial conditions were established, predictive models were run for 100 year simulations, incorporating varied effects of willow shading by reducing annual temperature amplitude and mean by similar magnitudes; in this way the summer thermal maximum is reduced, but the cold winter minimum is preserved. Note that potential winter insolation effects of trapped snow were not incorporated. 
The climate warming scenario was created by applying a trend to the thermal boundary that resulted in $\mathrm{a}+2.55^{\circ} \mathrm{C}$ change in mean temperature at $0.06 \mathrm{~m}$ depth after 100 years; the $2.55^{\circ} \mathrm{C}$ value was chosen by applying a conversion factor of 0.85 for "low shrub-scrub" land cover [Jorgenson and Kreig, 1988] on soils to the moderate Scenarios Network for Alaska and Arctic Planning (SNAP) [Scenerios Network for Alaska and Arctic Planning, University of Alaska, 2013] predicted air warming over the simulated time period. Little regional trend in recharge is predicted by SNAP, so the recharge boundary was left unchanged. Once the $+2.55^{\circ} \mathrm{C}$ background temperature trend was established, the climate warming model scenario was rerun with the added "strong willow effect" of $2^{\circ} \mathrm{C}$ summer shading and no summer recharge (model Sh2-0R-CW).

A time varying recharge boundary was set at the ground surface to represent three distinct phases: (1) winter, no recharge (ordinal days 0-100 and 275-365), (2) spring snowmelt recharge (days 100-120), and (3) summer recharge (days 120-365). Meltwater temperature was $0.5^{\circ} \mathrm{C}$, and volume was determined from average Fort Yukon data (SNOTEL \#961) as $0.47 \mathrm{~m}$ snow with 0.2 snow water equivalent. The summer recharge phase delivers $0.1 \mathrm{~m}$ of precipitation; this recharge was assigned a value of $12^{\circ} \mathrm{C}$ to represent observed area conditions, although models were found to be relatively insensitive to this assumed temperature. To simulate the effects of transpiration/interception by the willow shrub, summer recharge was set to $0 \mathrm{~m}$ ( $0 \mathrm{R}$ models), while the melt pulse was preserved as it was assumed that the shrubs are not foliated and therefore not using soil water at that time.

Various unsaturated soil properties were investigated, and simulations were found to be strongly sensitive to both the freezing function and residual saturation at strong negative (drying) pressure. Therefore, great care was taken to match model parameters with the general soil type observed in the field. A single homogeneous soil was used for all models and based on a classification of "silt-loam" [Jepsen et al., 2012b] and observations from soil pits. The unsaturated soil water freezing and soil water retention characteristics for this soil type were based on a recent laboratory investigation [Watanabe et al., 2011], as was the silt-loam porosity of 0.46 . The soil water freeze function (relating temperature to ice content) was simulated with a four-section piecewise linear function with a minimum residual unfrozen water content of $16.6 \%$ (of total porosity) at $-20^{\circ} \mathrm{C}$ (Figure S3). The soil water retention curve was simulated with a piecewise linear function with residual saturation at $50,000 \mathrm{kPa}$ of $8 \%$. The soil had a base permeability of $1 \times 10^{-12} \mathrm{~m}^{2}$, with a frozen minimum permeability of $1 \times 10^{-13} \mathrm{~m}^{2}$. The relatively small reduction in permeability when frozen was based on observation of water flow through frozen silt-loam, compared to other frozen soils that do not permit flow when frozen [Watanabe et al., 2011, 2013]; permeabilities less than approximately $1 \times 10^{-13} \mathrm{~m}^{2}$ essentially function as confining material within the model and could have induced surface ponding, a condition for which there was no field evidence.

\section{Results and Discussion}

Ground-based electrical geophysical surveys conducted in late summer 2011 and 2012 along a transect of mixed open meadow and willow shrub showed shallow zones with permafrost characteristics located proximal to maturing shrubs, while more open areas did not show evidence of frozen ground (Figures $1 \mathrm{~b}$ and $1 \mathrm{c}$ ). Manual frost and temperature probing confirmed these results, with comparable repeat measurements identifying some shallow frozen ground existing for at least 2 years, i.e., permafrost by definition. Modeling results presented below 
support these observations and provide unprecedented insight into ecologically driven permafrost aggradation in variably saturated conditions.

\subsection{Ecosystem-Driven Aggradation}

Results from the OM-R base model show seasonal frost and temperature propagation through time (Figure 2). Annual frost and temperature dynamics define envelopes that encompass the range of simulated conditions with depth along the profile; for OM-R, the maximum and mean shallow soil temperatures are 12.3 and $0.6^{\circ} \mathrm{C}$, respectively. Under the expected ambient conditions of the open meadow dried lake bed, appreciable permafrost does not form. Notably, there is annual downward propagation of ice from the previous winter through the soil peaks near the water table in early September, yet ice content drops to zero for the rest of the annual cycle (Figure 2a). This strong phase shift has important implications for field interpretations of frozen ground. The presence of low ice content deep frost late in the summer may indicate seasonally frozen ground rather than permafrost. The simulated low yearround ice saturation (3\% of porosity) at the water table in OM-R (Figures 2a and 4a) agrees with site observations from a soil pit dug in open meadow, where stiff soil and temperatures close to $0^{\circ} \mathrm{C}$ were detected in a discrete band just above the water table, which supports the OM-R model.

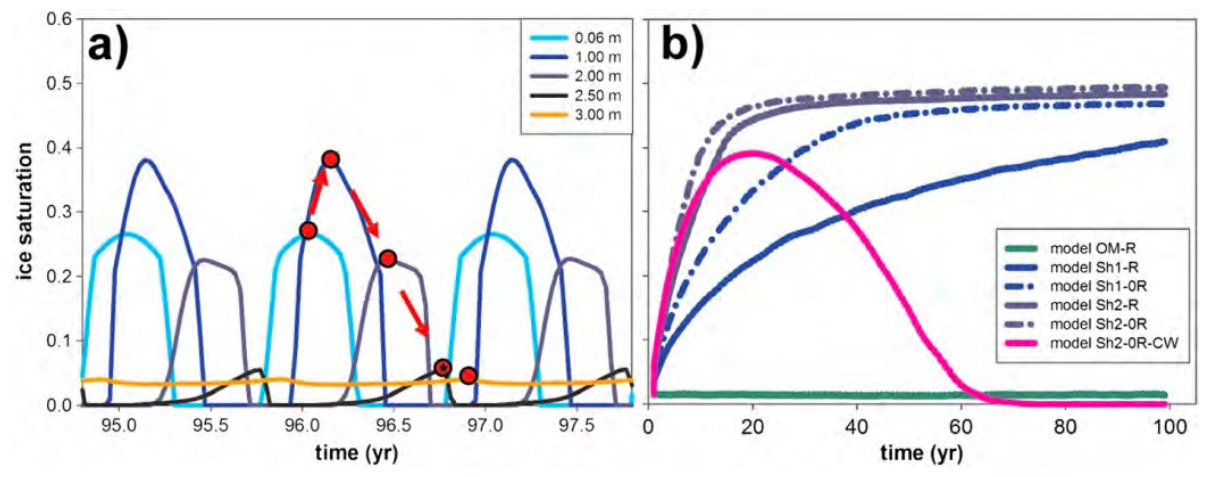

Figure 2. (a) Three year temperature time series for multiple depths in the open meadow model showing that ice saturation peaks around $1 \mathrm{~m}$ depth and propagates downward while shifting forward in phase with yearly peak ice content indicated by red dots; the starred dot corresponds to the time year of 2012 data collection. (b) Smoothed (1 year average) time series of ice saturation at $2.5 \mathrm{~m}$ depth in all models, showing the accelerated frost formation caused by uptake of summer recharge and permafrost aggradation and subsequent degradation under climate change.

Simulation OM-0R indicates that willow shrub uptake of summer recharge does not result in appreciable permafrost aggradation within the Twelvemile Lake basin. When recharge is removed from the baseline model, the original discrete band of ice saturation at the water table interface is slightly enhanced to $7 \%$; hence, shrub-driven reduction in recharge cannot explain the thick, shallow sequence of frost observed in the field beneath shrub areas. Recharge reduction has a much stronger effect when combined with summer shading. Figure $2 b$ shows how frost development at greater depth in the unsaturated zone, characterized by multiple model time series at $2.5 \mathrm{~m}$ depth, is greatly accelerated in the Sh1-R model when summer recharge is removed in Sh-0R. There is muted enhancement of freezing in the stronger shading Sh2-0R 
model, compared to Sh2-R, indicating the importance of unsaturated zone heat advection to permafrost aggradation peaks under moderate shading conditions. Thus, the uptake of summer recharge and subsequent reduction of infiltration alone does not result in strong permafrost aggradation, but when combined with summer shading recharge reduction does result in appreciable enhancement of freezing, particularly in the Sh1-0R model.

Thick sequences of new shallow permafrost accumulate in models Sh1-0R (5.7 m thick) and Sh2-0R (7.7 m thick), which have both shading and reduced recharge, as shown in Figures $4 \mathrm{~b}$ and $4 \mathrm{c}$, respectively. Dynamic steady state permafrost is $0.2 \mathrm{~m}$ shallower in model Sh2-0R at $1.6 \mathrm{~m}$ (Figures $3 \mathrm{a}$ and $4 \mathrm{c}$ ); this depth is within $0.16 \mathrm{~m}$ of that observed near willow shrub in the field. Much of the frost accumulation takes place in the unsaturated zone in the first 25 years, particularly with increased shading (Sh2-0R). As the unsaturated zone permafrost quasiequilibrates, substantial freezing of the saturated zone occurs over the remainder of the simulations. The Sh1-0R and Sh2-0R models are most dissimilar in quasi-equilibration time and saturated zone freezing dynamics. Ice saturation in the shallow aquifer of both models exceeds $50 \%$ of the available porosity, thus restricting flow and the advection of heat. This result shows how critical yet subtle differences in shrub growth and subsequent shading may have pronounced impacts on shallow groundwater flow and the resultant lake water budget.

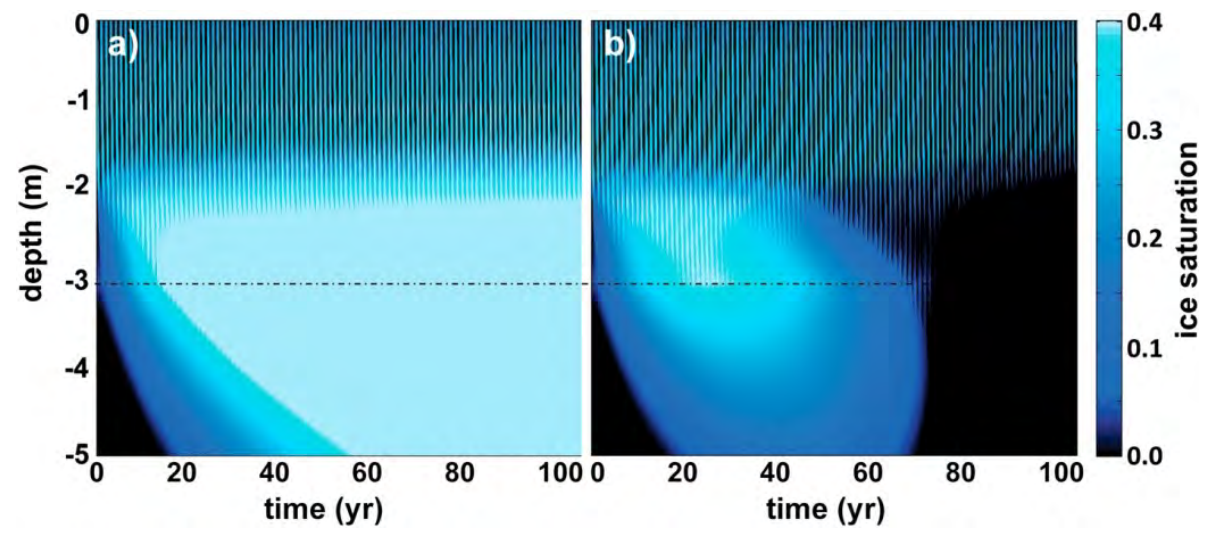

Figure 3. (a) Strong shrub effect model ice saturation (Sh2-R), where dashed line indicates static water table.

(b) Climate change model ice saturation (Sh2-0R-CW); ice saturation is defined as fraction of pore space filled with frozen water.

\subsection{Climate Warming Scenario}

Movies S1 and S2 illustrate how the annual thermal signal propagates downward, causing rapid permafrost aggradation just above the water table where total saturation is high (approximately 90\%). The static water table depth at $3 \mathrm{~m}$ chosen for this study likely influences these results; a shallower water table could promote initial permafrost formation within the saturated zone. As the yearly frost pulse approaches, the new permafrost there is freezing upward so that the two bands of frozen ground join, until the shallow zone thaws from above. The frost envelopes of sequential freezing and thawing above permafrost shown by the gray lines in Movies S1 and S2 define the active layer, which stabilizes relatively quickly ( $<25$ years) in terms of penetration depth for both models Sh1-0R and Sh2-0R. 


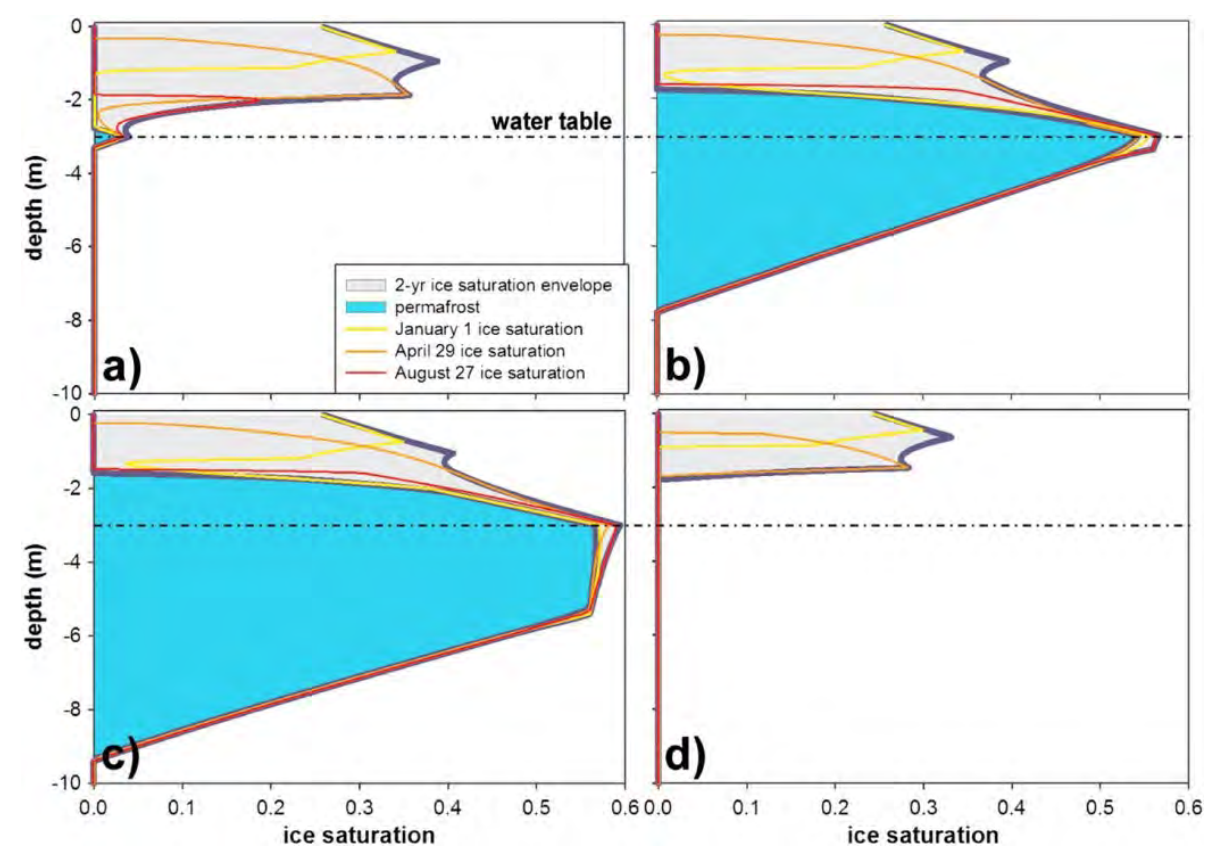

Figure 4. Ice saturation envelope encompassing annual frost variation (including three date specific profiles) and aggraded permafrost ice saturation after 99 years of simulation for the following models: (a) open-meadow $(\mathrm{OM}-\mathrm{R}),(\mathrm{b})$ moderate shrub effect (Sh1-OR), (c) strong shrub effect (Sh2-OR), and (d) strong shrub effect with climate change (Sh2-0R-CW).

The Arctic has been warming, and a $3^{\circ} \mathrm{C}$ mean air temperature rise is projected over the next 80 years for the Yukon Flats assuming midrange emissions [Scenerios Network for Alaska and Arctic Planning, University of Alaska, 2013]. This climate warming (CW) trend was imposed on the hydrologic scenario that yielded the thickest aggraded permafrost under current conditions (Sh2-0R) (Movie S3). The Sh2-0R-CW simulation (Figure 3b) shows initial permafrost aggradation on the scale of several meters in thickness, similar to Sh2-0R (Movie S2), though after approximately 20 years the simulations diverge and permafrost begins to degrade for Sh2-0R-CW. Ice saturation peaks at $45 \%$ with climate warming and $60 \%$ without warming. The maximum depth reached by permafrost subjected to climate warming is $6.1 \mathrm{~m}(9.3$ $\mathrm{m}$ with no warming), and this maximum occurs at year 45 , after which permafrost degrades. Under climate warming, frozen ground first thaws downward in the unsaturated zone, vanishing by year 69 (Figure 2b). Along with permafrost degradation, the seasonally active freeze/thaw layer thins from a zone extending from land surface to below the water table to a zone only reaching $1.8 \mathrm{~m}$ depth by 100 years (Figure 4d). This thinning is also accompanied by a broadening in the annual temperature envelope to incorporate temperatures at depths that are warmer than those observed in any other model (Figure S4); the envelope converges on the geothermal gradient at several degrees above zero approximately $3 \mathrm{~m}$ below the water table. The effects of expected air temperature increases on near-surface soil temperatures may be countered, at least to some degree, by reductions in the thickness and duration of snowpack [Bayard et al., 2005; Hardy et al., 2001] and particularly by the later timing of initial snow accumulation [Iwata et al., 2008]. The modeling approach presented here to represent climate change assumes that such effects of potential changes in snowpack are negligible or at least overshadowed by the 
influence of warming air temperatures in the study region. Future work incorporating expected snow-related trends is needed to test this assumption.

\section{Conclusions}

Global warming concerns have focused on the effects of increased air temperature on permafrost degradation, yet the present study reveals a mechanism to explain observed permafrost aggradation under current conditions. Recent large-scale geophysical characterization of frozen substrate beneath shrinking lakes in the Yukon Flats suggests that shallow permafrost distribution around lakes, as opposed to deep permafrost thaw beneath the lakes, may be driving changes in lake levels across the region [Jepsen et al., 2013]. Therefore, permafrost aggradation following lake recession and vegetation succession may be an important component in the cycle of lake or wetland contraction and expansion. Permafrost formation alters the surface water/groundwater exchange capacity and near-surface fluxes of water and solutes. Permafrost aggradation may act to reverse the net water flux to a receding lake, thereby promoting the natural cycle of lake level fluctuations observed in lake cores in the region [Anderson et al., 2013]. Should warming occur as predicted, however, simulation results point to termination of the lake retreat/ecosystem mechanism as a driver of permafrost aggradation before the turn of the next century.

\section{Acknowledgments}

We thank Emily Voytek, Jay Nolan, and Joshua Rose for assistance in the field and in processing data. Burke Minsley, Barret Kurylyk, and Audrey Sawyer have improved this work with their careful reviews. Funding for this project was provided by the U.S. Department of Defense under the Strategic Environmental Research and Development Program RC-2111, with additional support from the U.S. Geological Survey (USGS) Office of Groundwater, USGS National Research Program, and Groundwater Resources Programs. Any use of trade, firm, or product names is for descriptive purposes only and does not imply endorsement by the U.S. Government.

\section{References}

Al Nakshabandi, G., and H. Kohnke (1965), Thermal conductivity and diffusivity of soils as related to moisture tension and other physical properties, Agric. Meteorol., 2, 271-279.

Anderson, L., J. Birks, J. Rover, and N. Guldager (2013), Controls on recent Alaskan lake changes identified from water isotopes and remote sensing, Geophys. Res. Lett., 40, 34133418, doi:10.1002/grl.50672.

Avis, C. A., A. J. Weaver, and K. J. Meissner (2011), Reduction in areal extent of high-latitude wetlands in response to permafrost thaw, Nat. Geosci., 4(7), 444-448, doi:10.1038/ngeo1160.

Bayard, D., M. Stähli, A. Parriaux, and H. Frühler (2005), The influence of seasonally frozen soil on the snowmelt runoff at two Alpine sites in southern Switzerland, J. Hydrol., 309, 66-84, doi:10.1016/j.jhydrol.2004.11.012.

Christensen, T. R. (2004), Thawing sub-arctic permafrost: Effects on vegetation and methane emissions, Geophys. Res. Lett., 31, L04501, doi:10.1029/2003GL018680.

Hardy, J. P., P. M. Groffman, R. D. Fitzhugh, K. S. Henry, A. T. Welman, J. D. Demers, T. J. Fahey, C. T. Driscoll, G. L. Tierney, and S. Nolan (2001), Snow depth manipulation and its 
influence on soil frost and water dynamics in a northern hardwood forest, Biogeochemistry, 56(2), 151-174, doi:10.1023/A:1013036803050.

Iwata, Y., M. Hayashi, and T. Hirota (2008), Comparison of snowmelt infiltration under different soil-freezing conditions influenced by snow cover, Vadose Zone J., 7, 79-86, doi:10.2136/vzj2007.0089.

Jepsen, S. M., C. I. Voss, M. A. Walvoord, J. R. Rose, B. J. Minsley, and B. D. Smith (2012a), Sensitivity analysis of lake mass balance in discontinuous permafrost: The example of disappearing Twelvemile Lake, Yukon Flats, Alaska (USA), Hydrogeol. J., 21(1), 185-200, doi:10.1007/s10040-012-0896-5.

Jepsen, S. M., J. C. Koch, J. R. Rose, C. I. Voss, and M. A. Walvoord (2012b), Thermal and hydrological observations near Twelvemile Lake in discontinuous permafrost, Yukon Flats, Interior Alaska, September 2010-August 2011, Open-File Report 2012-1121, 25 p.

Jepsen, S. M., C. I. Voss, M. A. Walvoord, B. J. Minsley, and J. Rover (2013), Linkages between lake shrinkage/expansion and sublacustrine permafrost distribution determined from remote sensing of interior Alaska, USA, Geophys. Res. Lett., 40, 882-887, doi:10.1002/grl.50187.

Jorgenson, M. T., and R. A. Kreig (1988), A model for mapping permafrost distribution based on landscape component maps and climatic variables, in Proc. 5th International Conference on Permafrost, pp. 176-182, Tapir Publishers, Trondheim, Norway.

Jorgenson, M. T., C. H. Racine, J. C. Walters, and T. E. Osterkamp (2001), Permafrost degradation and ecological changes associated with a warming climate in central Alaska, Clim. Chang., 48, 551-579.

Jorgenson, M. T., V. Romanovsky, J. Harden, Y. Shur, J. O’Donnell, E. A. G. Schuur, M. Kanevskiy, and S. Marchenko (2010), Resilience and vulnerability of permafrost to climate change, Can. J. For. Res., 40(7), 1219-1236, doi:10.1139/X10-060.

Kurylyk, B. L., and K. Watanabe (2013), Review: The mathematical representation of freezing and thawing processes in variably-saturated, non-deformable soils, Adv. Water Resour., 60, 160-177, doi:10.1016/j.advwatres.2013.07.016.

Labrecque, S., D. Lacelle, C. R. Duguay, B. Lauriol, and J. Hawkings (2009), Contemporary (1951-2001) evolution of lakes in the Old Crow basin, northern Yukon, Canada: Remote sensing, numerical modeling, and stable isotope analysis, Arctic, 62(2), 225-238.

Mackay, J. R. (1997), The full-scale field experiment (1978-1995) on the growth of permafrost by means of lake drainage, western Arctic coast: A discussion of the method and some results, Can. J. Earth Sci., 34(1), 7-19.

McKenzie, J. M., and C. I. Voss (2013), Permafrost thaw in a nested groundwater-flow system, Hydrogeol. J., 21(1), 299-316, doi:10.1007/s10040-012-0942-3.

McKenzie, J. M., C. I. Voss, and D. I. Siegel (2007), Groundwater flow with energy transport and water-ice phase change: Numerical simula- tions, benchmarks, and application to freezing in peat bogs, Adv. Water Resour., 30(4), 966-983, doi:10.1016/j.advwatres.2006.08.008.

Minsley, B. J., et al. (2012), Airborne electromagnetic imaging of discontinuous permafrost, Geophys. Res. Lett., 39, L02503, doi:10.1029/2011GL050079.

Scenerios Network for Alaska and Arctic Planning, University of Alaska (2013), SNAP: Maps. [Available at http://www.snap.uaf.edu.]

Shur, Y. L., and M. T. Jorgenson (2007), Patterns of permafrost formation and degradation in relation to climate and ecosystems, 19 (December 2006), 7-19, doi:10.1002/ppp.

Smith, M. W. (1975), Microclimatic influences on ground temperatures and permafrost distribution, Mackenzie Delta, Northwest Territories, Can. J. Earth Sci., 12, 1421-1438. 
Smith, L. C., Y. Sheng, G. M. MacDonald, and L. D. Hinzman (2005), Disappearing arctic lakes, Science (80-. ), 208(5727), 1429, doi:10.1126/science.1108142.

Sturm, M., J. Schimel, G. Michaelson, J. M. Welker, S. F. Oberbauer, G. E. Liston, J.

Fahnestock, and V. E. Romanovsky (2005), Winter biological processes could help convert arctic tundra to shrubland, BioScience, 55(1), 17, doi:10.1641/00063568(2005)055[0017:WBPCHC]2.0.CO;2.

Voss, C. I., and A. M. Provost (2002), SUTRA: A Model for Saturated-Unsaturated, VariableDensity Ground-Water Flow with Solute or Energy Transport, Reston, Va.

Watanabe, K., T. Kito, T. Wake, and M. Sakai (2011), Freezing experiments on unsaturated sand, loam and silt loam, Ann. Glaciol., 52(58), 37-43, doi:10.3189/172756411797252220.

Watanabe, K., T. Kito, S. Dun, J. Q. Wu, R. C. Greer, and M. Flury (2013), Water infiltration into a frozen soil with simultaneous melting of the frozen layer, Vadose Zo. J., 12(1), doi:10.2136/vzj2011.0188.

Wellman, T. P., C. I. Voss, and M. A. Walvoord (2013), Impacts of climate, lake size, and supraand sub-permafrost groundwater flow on lake-talik evolution, Yukon Flats, Alaska (USA), Hydrogeol. J., 21(1), 281-298, doi:10.1007/s10040-012-0941-4.

Woo, M.-K., and T. C. Winter (1993), The role of permafrost and seasonal frost in the hydrology of northern wetlands in North America, J. Hydrol., 141, 5-31.

Yoshikawa, K., and L. D. Hinzman (2003), Shrinking thermokarst ponds and groundwater dynamics in discontinuous permafrost near council, Alaska, Permafr. Periglac. Process., 14(2), 151-160, doi:10.1002/ppp.451. 